\begin{tabular}{rr}
\hline \hline & $811.163 .41 ’ 342.8$ \\
$811.163 .41 ’ 366.625$ \\
https://doi.org/10.18485/msc.2017.46.3.ch1
\end{tabular}

\author{
Ана С. БАТАС \\ Филолошки факултет \\ Универзитета у Београду
}

\title{
АКЦЕНАТ ИМПЕРАТИВА ГЛАГОЛА (II)
}

\begin{abstract}
У раду се бавимо анализом акцената инфинитива, презента и императива на основу хиљаду најфреквентнијих глагола. Издвојено је неколико различитих случајева према томе да ли се акцент императива поклапа са акцентом инфинитива, презента или има засебан акценат, другачији од осталих испитаних облика.
\end{abstract}

Кључне речи: акценатске парадигме, акценат императива

\section{Увод}

Овај рад се наставља на истраживање представљено на 45. међународном научном састанку слависта у Вукове дане (Батас 2015). У претходном истраживању бавили смо се глаголима са инфинитивном основом чији је наставак - $a$, односно глаголима II, IVб, V и VII Стевановићеве врсте, ексцерпираним из „Обратног речника савременог српског језика (OP)”. Пошто би преостале глаголске врсте, чији су наставци инфинитивних основа различити, било знатно теже ексцерпирати на тај начин, определили смо се да у овом раду испитамо акценат императива хиљаду најфреквентнијих глагола из „Корпуса савременог српског језика” (КССЈ), без обзира на врсту којој припадају ${ }^{1}$. Акцентски дублети су проверавани у „Речнику српскога језика” (PCJ), а повремено и у осталим акцентованим речницима.

О грађењу императива нема никакве сагласности међу граматичарима. Нема међу њима слагања нити око основе императива, нити око његових наставака (Николић $2007^{2}$ и Стакић 2003). И док се о његовом грађењу доста писало, нема рада који се бави искључиво његовим акцентом. Сматрамо пак

\footnotetext{
${ }^{1}$ Овом приликом захваљујем се Милошу Утвићу, који је направио листу најфреквентнијих глагола и тиме омогућио настанак овог истраживања.

${ }^{2}$ Пошто се не бавимо морфолошким аспектима овог глаголског облика, за даља разматрања о грађењу овог глаголског облика в. Николић 2007.
} 
да је истраживање акцента облика императива важно зато што заједно са истраживањима овог типа јесте ${ }^{3}$ доприноси систематичном опису акценатских парадигми глагола у српском језику, а може бити од користи и онима који се надаље буду бавили грађењем императива из синхронијске перспективе.

Акцентом свих глаголских облика, па и императива, највише су се бавили Ђ. Даничић (1925) и М. Стевановић (51989). Они глаголе разврставају по глаголским парадигмама, а затим се унутар њих баве акцентом глагола, што je - као што ћемо видети - супротно начину на који се у овом раду прилази акценту глагола.

Ђ. Даничић (1925) представља глаголе или појединачно или групише глаголе исте творбене основе (истог корена), обавезно акцентујући различите глаголске облике, и то најчешће без коментара. Уколико се коментар у вези са акцентом императива појави, онда се налази уз конкретни глагол (групу глагола), па се тако, на пример, каже да се у императиву акценат код глагола чути мења у дугосилазни (idem: 101), да акценат императива глагола знати може бити знаj, знајјмо, знајте или знӓди (idem: 105), а да краткосилазном акценту презента глагола $u \hbar u$ одговара краткоузлазни у императиву (idem: 107) итд.

О акценту овог глаголског облика највише се може нађи у коментарима

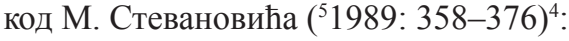

1. Сви облици, па и императив, имају исте акценте (јёсти - јёдемм $-j е ̈ \partial u)$;

2. Императив има акценат презента (прёсти - пре́дём - пре́ди);

3. Императив има акценат инфинитива (рёћи - рёчём - рёци, орати -ӧрём-о̀рu).

4. Императив има посебан акценат (слӓти - мӓљеем- мајљи, дрџжати - дрюим - држи).

5. Акценат и инфинитива и презента се дуљи у императиву (чӱти $-4 \ddot{j} \bar{j} \bar{M}-4 \hat{j})^{5}$.

6. Акценат презента се дуљи у императиву (ковати - кујјемм - куј).

За разлику од претходних аутора, у граматици Барић et al. (1997: 243) представљају се случајеви груписани према наставцима императива:

1) Глаголи који граде императив наставцима $-u$, -имо, -ите имају у тим облицима обично нагласак инфинитива: ба́и̧и - ба́цฺити, плети - плёсти, вйди - вйдјети, ви́чи - вйкати.

2) Глаголи с наставцима $-j$, -jмо, -jmе и с наставцима -Ø, -мо, -те имају дуг самогласник испред наставка:

${ }^{3}$ Од досадашњих истраживања у вези са акцентом појединих глаголских облика издвајамо радове Ј. Јокановић Михајлов 2012: 81-88 (о акценту радног гл. придева) и М. Стевановића 1991: 57-66 (о акценту радног гл. придева) и 1991: 66-75 (о акценту аориста).

${ }^{4}$ Коментари су расути по глаголским парадигмама, а приложена систематизација је наша.

${ }^{5} \mathrm{M}$. Стевановић не убраја глагол типа снити - сним у овакав тип глагола, пропустивши да наведе да се дуг акценат јавља и у императиву поред имперфекта и глаголског прилога прошлог, које наводи (Стевановић 51989: 371). 


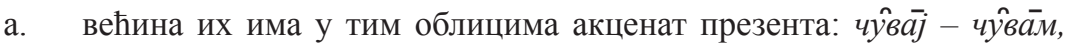

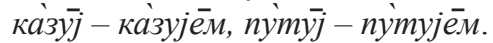

b. они глаголи који у једнини имају једносложни облик имају испред наставка дугосилазни акценат: чурิ - чујемем, пиј - пијеме

М. Николић (2007), будући да се у раду расправља о грађењу императива, на крају рада се осврће на оне случајеве у којима се разликују акценти презента и императива:

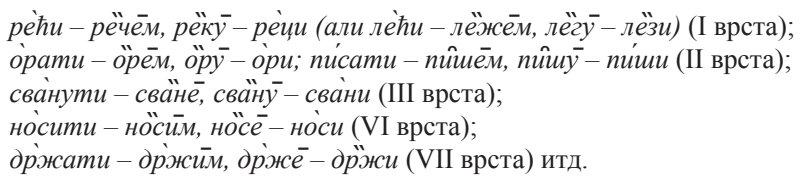

Као што је већ истакнуто, овај рад је заснован на хиљаду најфреквентнијих глагола, а испитивани су акценти императива, презента и инфинитива. У раду ћемо, како је то учињено и у Николић 2007, од свих облика наводити редом следећа четири:

a) акценат инфинитива;

б) акценат 1. лица једнине презента (2. и 3. лице једнине имају исти акценат ${ }^{7}$ ) и акценат 3. лица множине презента (1. и 2. лице множине имају или исти акценат као облици у једнини или код неких глагола имају дублетне облике, на пример жѐлети (жѐлимо и жели́мо), иммати (има̄мо и има́мо), читтати (чита̄мо и чита́мо)

в) акценат 2. лица једнине императива (1. и 2. лице множине имају исти акценат).

Прво ћемо у раду груписати глаголе према прозодијским карактеристикама, и то следећим редом: глаголи са дугосилазним акцентом у инфинитиву, са дугоузлазним, са краткосилазним и на крају са краткоузлазним (в. т. 1).

Потом ћемо се глаголе класификовати према томе у каквом односу са осталим облицима стоји акценат императива (в. т. 2).

\section{1. Акценатске парадигме}

У настојању да добијемо што мањи број акценатских парадигми за класификацију користили само акценат инфинитива, према којем су сви глаголи груписани, и акценат презента. Ако им се акценат 1. и 3. лица презента разликују, такви глаголи су издвојени у посебне подтипове.

\footnotetext{
${ }^{6}$ Сложене глаголе помињу и М. Стевановић ( $\left.{ }^{5} 1989\right)$ и Барић et al. (1997).

${ }^{7}$ Акценат ових облика се једино разликује код глагола јесам, хтети и моћи, али се њима у раду нисмо бавили.
} 


\section{А) Глаголи са дугосилазним акиентом у инфинитиву}

\section{1) паิмтити - па̂мтим}

Веома мало глагола спада у овај тип, како међу хиљаду најчешћих, тако и међу глаголима II, IVb, V, VII врсте, које смо испитивали у Батас 2015. Тада смо нашли на глаголе као што су саннкати се, пра厃зниковати, као и на гла-

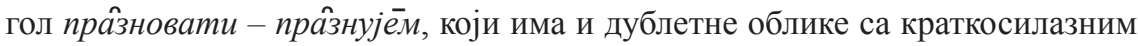
акцентом празновати $=$ прӓзновати ${ }^{8}$. Глагол ,памтити” у говору неких информатора из четвороакценатских система почиње да се мења по парадигми писати - пимеем ${ }^{9}$.

Са дугосилазним акцентом у инфинитиву јавља се и глагол клети, а напоредо се јавља и са дугоузлазним (клетии = кле́ти). У презенту има краткоузлазни акценат кунемм, кунуд. Ово је једини глагол у нашем корпусу чији акценти алтернирају на овакав начин, па се само због тога сврстава у глаголе са дугосилазним у инфинитиву.

\section{Б. Глаголи са дугоузлазним акиентом у инфинитиву}

\section{2) ли́чити - ли́чйм}

Код овог типа и инфинитив и презент у целини имају дугоузлазни акценат. У глаголе који имају дугоузлазни акценат на првом слогу спадају: тр́пети, са́ветовати, да́вати, ћуттати, ра́зликовати, сме́шити се ${ }^{10}$, ви́рити, спа́ссити (и спа́сти), зву́чати, бра́нити итд.

Као подтип ове акценатске парадигме могу се издвојити глаголи који дугоузлазни имају на антепенултими у инфинитиву ${ }^{11}$, као што је глагол дожи́вети - доживимм, дожи́ве- - дожи́ви. У њих спадају још и: заћу́тати, полу́дети, пребле́дети, као и отиіћu, извући, пову́ћи, обу́ћu, навући, одвуіћи, који имају дублетне облике отиंћu $=$ отић $и$, извући $=$ извући

\section{3) пи́сати - пиюшем}

За разлику од претходног типа, глаголи ове акценатске парадигме имају дугосилазни акценат 1. лицу једнине презента. У оквиру њега могу се већ на основу акцента 3. лица множине презента издвојити два подтипа:

a) пи́сати - пиюшем- пишшу

У оквиру овог подтипа, сва лица презента, па и 3. лице множине, имају дугосилазни акценат. Следећи глаголи имају такве акцен-

\footnotetext{
8 Знаком ,=" обележаваћемо да су примери акценатски дублети.

${ }^{9}$ Такву потврду добили смо усмено од информатора из Горњег Милановца.

${ }^{10}$ Пошто у КССЈ нису раздвојени рефлексивни од нерефлексивних глагола, рефлексивне глаголе наводимо само тамо где у РСЈ није забележен нерефлексивни глагол.

${ }^{11}$ Међу првих 1000 глагола, сви глаголи овог типа, ако имају дугоузлазни ван првог слога, имају га на антепенултими. Међутим, међу мање фреквентним глаголима, вероватно ће се наћи и они са другачијим местом акцента.
} 
те: ка́зати, ди́сати, ска́кати, кре́нути, ви́кати, скре́нути, га́јити, га́ссити, гу'шити, хра́нити, хва́лити, као и до'ћu, на́ћи, прићи, по'ћu,

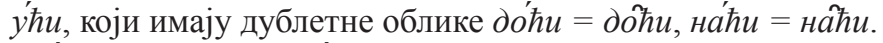

б) спа́вати - спаюва̄м, спавају

За разлику од претходног подтипа, 3. лице множине презента код ових глагола има дугоузлазни акценат, који се поклапа са акцентом инфинитива. Међу њих спадају следећи глаголи: чу́вати, бирати, ди́рати, ду'вати, ку́пати, лугпати, ме́вати, ме́шати, морати, на́дати се ${ }^{12}$, питтати, про́бати, ру́чати итд.

\section{4) напи́сати - на̀пйше̄м}

У инфинитиву ови глаголи имају дугоузлазни акценат везан за антепенултиму, а у 1. лицу једнине презента краткоузлазни на антепенултими са две неакцентоване постакценатске дужине на пенултими и ултими. Узлазни акценти код глагола на префиксу алтернирају са силазним акцентима на основи мотивног глагола (метатонијско преношење акцената). Због тога што је њихов акценат предвидив, овај тип би се могао третирати заједно са глаголима типа писсати - пиией. Ипак, то у овом раду не чинимо, јер има и оних глагола који имају исти однос акцената у инфинитиву и презента, а да немају у систему парњак (мотивни глагол) са којим су акценти у алтернацији.

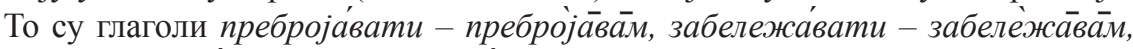
онерасположа́вати - онерасположа̄ва̄м (Батас 2015).

У оквиру овог типа могла би се, паралелно подтиповима писсати-пииём,

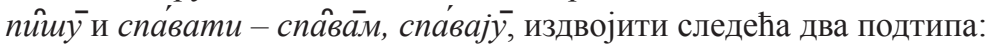

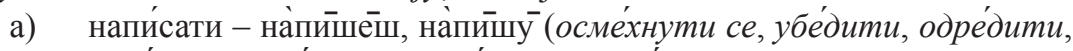
обја́вити, узда́хнути, дока́зати, повра́тити)

б) преспа́вати - пресспавам, преспа́вају (посма́трати, пона́вљати, уживати, упиттати, добијати, захте́вати, дога́ђати се).

Овој акценатској парадигми могли би се, условно речено, прикључити и глаголи I врсте, који у инфинитиву имају дугоузлазни на пенултими, а у презенту краткоузлазни на антепенултими са две постакценатске дужине. Такви

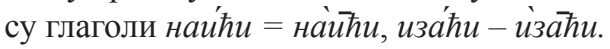

\section{5) сарађи́вати - сара̀ђује̄м}

У инфинитиву ови глаголи, као и глаголи претходног типа, имају дугоузлазни акценат везан за антепенултиму, али за разлику од претходног типа, ови глаголи у презенту имају само једну, презентску, дужину, док постакценатска дужина на пенултими изостаје. У ову групу, на пример, спадају: казивати, испитиввати, доказивати, осмехивати, упућивати, везивати, изненађивати,

12 Пошто у речнику који је састављен на основу КССЈ нису раздвајани хомографи, као што ни рефлексивни глаголи нису раздвајани од нерефлексивних, можемо само да претпоставимо да се ради о глаголу „на́дати се” (у значењу „имати наде, очекивати са неком вероватноћом” (РСJ)), а не глагол „наддати” (у значењу „створити, (по)дићи (буку, вику, ларму, галаму и сл.)” (РСЈ)). 
прераспоређи́вати (последња два из Батас 2015). Сви глаголи овог акценатског типа спадају у глаголе IVб врсте.

\section{В. Глаголи са краткосилазним акиентом у инфинитиву}

\section{6) вёровати - вёрује̄м}

Глаголи са силазним акцентима имају и мање акценатских типова и мање се акценат разликује међу облицима. Код овог типа глагола сви испитивани облици имају исти акценат пёвати - пёвам, пёвају - пёвај, осим императива, чији ћемо акценат коментарисати у даљем тексту.

Краткосилазни акценат у инфинитиву има и глагол звӓти - зовеем, зову. Међутим, у презенту има краткоузлазни акценат. И глаголи красти и сећи имају краткосилазни у инфинитиву, али је њихов презент са дугоузлазним акцентима (крӓсти - кра́дём, кра́дуे).

\section{Г. Глаголи са краткоузлазним акиентом у инфинитиву ${ }^{13}$}

\section{7) пѐћи - пѐчѐм}

Међу глаголима са краткоузлазним акцентом на 1. слогу налази се највећи број глагола, мало више од петине анализираних. Ако се на узима у обзир број слогова, односно место акцента гледано са десне стране, у ову акценатску парадигму спадају и: уттицати, притиснути, осетити, ухватити, одлазити, направити, измислити, прѐдати, поверовати, појести итд. Краткоузлазни акценат код глагола насталих префиксацијом настао је у метатонијском померању краткосилазног акцента: на̀правити $<$ прӓвити.

Међу њих спадају глаголи и: забо’равити, разумети, недостајати, рачу̀нати, препознати, почрвѐнети, као и глаголи довёсти, повёсти, извести, који имају дублетне облике довѐсти = довести. Глаголи принети, унетти, понетти, занетти могу такође спадати у овај тип ${ }^{14}$, а дублетне облике имају у презенту принесем $=$ принесем. Глагол изајбрати - изајберемм такође би се могао уврстити у овај тип, а дублетни су његови облици у презенту: изајберем = изаберемем.

13 У Батас 2015 применили смо другачију класификацију глагола са краткоузлазним акцентом. С обзиром на то да је истраживање спроведено на далеко обимнијем корпусу, издвојиле су је још неке акценатске парадигме, а као критеријум класификације узимано је и место акцентованог слога.

${ }^{14}$ Ови глаголи у инфинитиву имају постакценатску дужину на слогу иза акцента. На основу те особине, могли би чинити и самостални тип. У овом раду нисмо (не)постојање постакценатске дужине узимали као критеријум за класификацију акценатских парадигми, што не значи да то не би било оправдано. 


\section{8) изгу̀бити - иззгубйм}

У оквиру овог акценатског типа инфинитив има краткоузлазни акценат на другом слогу, док презент има исти акценат на првом слогу, односно ако је акценат у инфинитиву на трећем слогу, у презенту ће бити на другом, што значи да се акценат презента увек налази за један слог ближе почетку речи. У овај тип спадају глаголи: говорити, учинити, отворити, напустити, догодити се, опростити, научити, замо’лити, обојити, подноссити, изводити, утонути, прекрстити).

Занимљиво је да акценат појединих глагола из ове групе није задовољавао фонолошки предуслов да се пренесе на префикс, пошто је на мотивном глаголу био краткоузлазни акценат, али се ипак пренео (в. следећу табелу).

\begin{tabular}{|c|c|c|c|}
\hline \multicolumn{2}{|c|}{ Испуњава услове } & \multicolumn{2}{|c|}{ Не испуњава услове } \\
\hline Мотивни глагол & Изведени глагол & Мотивни глагол & Изведени глагол \\
\hline вӧдимм & на̀водим & чйнӣм & учинимм \\
\hline мӧлим & за̀молим & учимм & науучим \\
\hline но“сим & поднносйм & бојимм & оббојимм \\
\hline вӧдим & иззводимм & крстим & прѐкрстим \\
\hline
\end{tabular}

Неки глаголи овог типа имају дублетне облике у инфинитиву, као што су

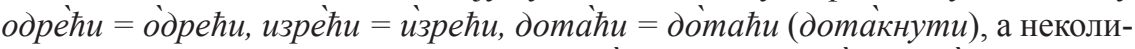
цина има дублетне облике и у презенту: одрекнем $=$ одрѐчем $=$ одрречём.

Као подтип ове акценатске парадигме јављају се глаголи код којих је краткоузлазни на трећем слогу и инфинитиву и императиву, а на другом слогу у презенту: одговорити, ослободити, задовољити, установити, упозорити итд.

У ове глаголе спадају и глаголи типа становати ${ }^{15}$ - ста̀нује-м (nутовати, шапутати, куповати, дуговати, пословати, руковати (рукујём) = руековати (рӱкујём), одиграти = о̀дирати).

\section{9) слѐгнути - слёгне̄м}

Глаголи овог типа имају краткоузлазни акценат у инфинитиву, а краткосилазни у презенту. У њих спадају глаголи: волети, открити ${ }^{16}$, пустити,

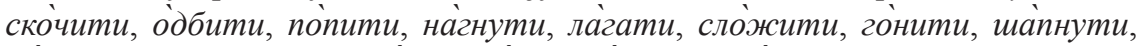

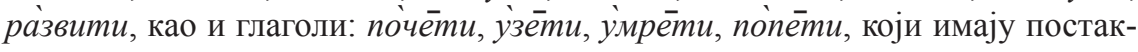
ценатске дужине на слогу после краткоузлазног акцента.

${ }^{15}$ Код бројних говорника из четвороакценатских система може се чути краткосилазни акценат на првом слогу код ових глагола. Сматрамо да је код њих уопштио акценат радног глаголског придева (путо̀вати - пйтовао, пуитова̄ла).

${ }^{16}$ Мотивни глагол гласи крӥти - крӥје̄м, због чега би изведени глагол требало да гласи оेmкрити - оेткријём, уместо отткрити - ӧткријём, што га сврстава у изузетке од глагола код којих долази до метатонијског преношења. 
Ако од ових глагола настану глаголи префиксацијом, спадају у глаголе 8 . типа (оне који испуњавају фонолошке услове).

На основу акцената у инфинитиву и 1. лицу једнине презента, глагол играти - йграмм спада у ову групу. Међутим његови акценти у 3. лицу множине презента и у императиву чине га изузетком: $\dot{z} р a j \bar{y}-\ddot{u z p} \overline{a j}{ }^{17}$.

\section{0) иззеети - изнѐсе̄м}

Ови глаголи имају у инфинитиву акценат на првом слогу, а у презенту на другом слогу: изнёти - изнесем, за разлику од 9. типа, где је инфинитив имао акценат на другом (или унутрашњем слогу), а презент на првом (или унутрашњем, али за један слог ближе почетку речи). Глагола који спадају у ову акценатску парадигму има мало у испитаном корпусу (позвати, назввати, проклёти, зајклети), а доста њих је има дублетне облике у презенту изнетти

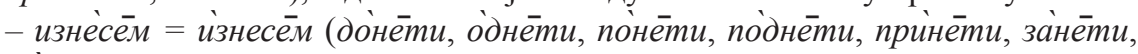
нанетии).

У ову групу сврстали смо и глаголе украсти и прѐсећи према акценту инфинитива, а у презенту имају дугоузлазне акценте на другом слогу - укра́дём и пресе́чём.

\section{2. Акценат императива према акценту осталих облика}

\section{1) памтити - памтимм}

Императив код глагола који спадају у ову акценатску парадигму има исти акценат као и инфинитив и презент: памтити - памтимм, па̂мтё- памти.

\section{2) личити - личим}

Императив глагола овог типа исти акценат као инфинитив и сва лица презента: ли́чити - ли́чим, личче- - ли́чи.

3) пи́сати - пиิшем

a) пи́сати - пише-м, пиишу

Императив код глагола овог акценатског подтипа има акценат као инфинитив: пи́сати - пишемм, пиюшу - пи́ши.

б) спа́вати - спаввам, спа́вају

Императив ових глагола има акценат као 1. лице једнине презента: спа́вати - спаิва̄м, спа́вају - спа̂вај ${ }^{18}$.

\footnotetext{
${ }^{17}$ М. Стевановић (51989: 358-376) издваја и тип у којем се у императиву дуљи акцента презента, али не и акценат инфинитива, као што је глагол ковати - кӱjём, кýj $\bar{y}, \kappa \hat{y j}$, али таквих глагола међу најчешћих хиљаду глагола нема.

${ }^{18}$ Сви императиви са наставком -ј имају испред наставка за императив постакценатску дужину, што је и раније у литератури потврђено, нпр. Барић et al. 1997: 243.
} 


\section{4) напи́сати - на̀пӣшѐ}

a) напи́сати - на̀пиешёш, на̀пиешу

Императив овог подтипа има исти акценат као инфинитив: написсати - на̀пиешёш, на̀пӣ̈у - напи́ши.

б) преспа́вати - преспава̄м, преспа́вају

А императив овог подтипа има исти акценат као 1. лице једнине презента:

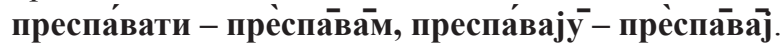

\section{5) сарађи́вати - сарађђује̄м}

Императив има исти акценат као презент и у 2. лицу једнине увек се налази на пенултими: сарађи́вати - сарађујём - сара̀ђују - сара̀ђу̀

\section{6) вёровати - вёрујём}

Императив код глагола овог типа има различите акценте: код једних остаје краткосилазни, код других има краткоузлазни, а код трећих дугосилазни акценат.

а) пёвати - пёвамм, пёвају - пёвај (вёровати, дӥзати, јӓхати, брӥнути, трегнути, мийати, клӥмнути, гурнути)

б) сла"ти - ша"љем, шӓљу - шајљи (прӓти, брӓти $\left.{ }^{19}\right)$

в) пйти - пијејем, пйуу - пиј (чӱти, крӥти, збӥти)

У последњем типу јавља се у императиву морфофонолошки условљен дугосилазни акценат. Сви императиви са наставком -j имају дугу слог пред наставком, а пошто је у овим случајевима основа императива једносложна, онда се уместо постакценатске дужине јавља дуљење акцента. Осим њих, још три глагола са краткосилазним у инфинитиву имају и у презенту дугосилазни акценат морфофонолошки условљен. То су глаголи дӓти, знӓти, смёти (знӓти - знам, знаају - зна̂).

Глаголе звӓти - зовём и крӓсти - кра́дём сврстали смо у недостатку сличних глагола у овај тип. Њихов је императив једнак презенту: звӓти зовеём, зовуу - зови и крӓсти - кра́дём, кра́ду - кра́ди.

\section{7) пѐһ̆ - пѐче̄м}

Што се акцента императива, има глагола код чији императив има исти акценат као инфинитив и презент, а има и глагола чији императив има посебан акценат. Могу се, према томе, издвојити следеће две групе:

а) пѐћи - пѐчем, пѐку - пѐци (уттицати, притиснути, осетити, уххватити, оддазити, на̀правити, измислити, прѐдати, поверовати, појести).

б) држати - држим, држе- - др"жи (сѐдети, бёжати, обрати, прибрати, опрати, послати). Глаголи сѐдети и бёжати, као и глагол држати, имају краткосилазни акценат у императиву - сёди

${ }^{19}$ Глагол брати преузет је из корпуса Батас 2015 пошто се не налази међу првих 1000 глагола. 
и бёжи, док глаголи обрати, прибрати, опрати и послати имају краткоузлазни акценат на другом слогу - обери, прибѐри, опѐри и помајьи.

\section{8) изгу்бити - иззгубим}

Код великог броја ових глагола акценат императива се поклапа са акцентом инфинитива, а код неколицине са акцентом презента:

a) изгуббити - изгубим, изгубе- - изгубби (говорити, учинити, отворити, напустити, догодити се, опросттит, научити, замолити, обојити, подносити, изводити, утонути, прекрстити). Код ових глагола акценат императива се поклапа са акцентом инфинитива.

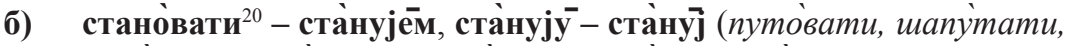
куповати, дуговати, пословати, руковати (рукујемм) = рӱковати (рӱкујём), одиграти = о̀играти). Код ових глагола се акценат императива поклапа са акцентом оба испитана облика презента.

\section{9) слеггути - слёгнём}

Глаголи овог типа имају краткоузлазни акценат у инфинитиву, а краткосилазни у презенту. Императив ових глагола има исти акценат као инфинитив - краткоузлазни: слеггнути - слёгнем, слёгну - слѐгни.

\section{0) изнетти - изнѐемм}

Ови глаголи имају у инфинитиву акценат на првом слогу, а у презенту и императиву на другом слогу: изнети - изнѐемм, изнѐс- изнѐси.

У ову групу сврстали смо и глаголе украсти и пресећи према акценту инфинитива, а у презенту имају дугоузлазне акценте на другом слогу - укра́дём и пресе́чём. Њихови облици императива имају такође дугоузлазни акценат.

На основу изложених акценатских парадигми и на основу односа акцент императив и осталих испитаних облика, издвојили смо неколико случајева:

- $\quad$ сви испитани облици имају исти акценат, па се акценат императива поклапа и са акцентом инфинитива и са акцентом презента;

- императив има исти акценат као инфинитив, али различит од акцента презента;

- императив има исти акценат као оба испитана облика презента, али различит од акцента инфинитива;

- императив има исти акценат као 1. лице једнине презента, а различит акценат од 3. лица множине презента и инфинитива;

- императив има свој акценат, различит од свих испитаних облика.

${ }^{20}$ Код бројних говорника из четвороакценатских система може се чути краткосилазни акценат на првом слогу код ових глагола. Сматрамо да је код њих уопштио акценат радног глаголског придева (путо̀вати - пӱтовао, пӱтова̄ла). 


\section{1. Сви облици имају исти акценат}

Акценатске парадигме у којима сви испитивани облици имају исти акценат јесу:

1. тип: паммтити - памтимм, памте- - памтти

2. тип: ли́чити - ли́чйм, ли́че- - ли́чи

6. тип: пёвати - пёвам, пёвају - пёвај

7. тип: пећи - печемм, пеку- - пеци

\section{2. Акценат императива исти као акценат инфинитива}

У следећим акценатским парадигмама императив има исти акценат као инфинитив:

3а. тип: пи́сати - пиюшемм, пиิшӯ- пи́ши

4a. тип: напи́сати - на̀пиешёш, на̀пйшу - напи́ши

8. тип: изгу̀бити - изгубйм, иззгубе--изгубби

9. тип: слѐгнути - слёгнем, слёгну- - слёгни

\section{3. Акиенат императива исти као акиенат оба облика презента}

Императив има исти акценат и као 1. лице једнине и као 3. лице множине презента у следећим акценатским парадигмама:

5. тип: сарађивати - сарађђује̄м - сара̀ђуј $\bar{y}$ - сара̀ђу

8. тип: становати - ста丿нујем, ста丿нују - ста̀нуј

10. тип: изнети - изнесемм, изнесу- - изнѐси

\section{4. Акиенат императива исти као 1. лице једнине презента}

Следеће акценатске парадигме имају исти акценат у императиву и у 1. лицу једнине презента, а акценат им се разликује од инфинитива и од 3. лица множине презента:

3б. тип: спа́вати - спа̂вамм, спа́вају - спаิвај

4б. тип: преспа́вати - прѐспа̄ва̄м, преспа́вају - прѐспавај

Глаголи са једносложним обликом 1. лица једнине презента и 2. лица једнине императива 6в типа, као што је глагол зна”ти - знам, знају, знај имају дугосилазни акценат у 1 . лицу једнине презента и у императиву.

\section{5. Императив има свој акценат}

У следећим акценатским парадигмама императив има акценат који се разликује и од акцента инфинитива и од акцента оба облика презента:

6. тип: слӓти - шӓљем, шӓљу - ша̀љи

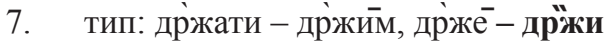

Глаголи са једносложним обликом 2. лице једнине императива 6. типа, као што је глагол пйти - пйјем, пйју - пй. 
Пре но што пређемо на закључак, укратко ћемо се осврнути на разлике између овог истраживања и претходних. За разлику од М. Стевановића ( ${ }^{5} 1989:$ 358-376), који издваја само случајеве у којима се акценат императива поклапа са акцентом презента, издвојили смо и случајеве у којима се поклапа са акцентом 1. лица једнине презента, али не и 3. лица множине. Такође смо као посебан тип навели оне случајеве у којима се сви акценти поклапају. М. Стевановић је пак раздвојио случајеве у којима се акценат императива добија дуљењем акцента инфинитива и презента и оне у којима се добија дуљењем акцента презента, док смо их ми груписали у тип у којем императив има засебан акценат.

Што се тиче тврдње из Барић et al. (1997: 243) да глаголи који граде императив наставцима $-u$, -имо, -ите имају у тим облицима обично нагласак инфинитива, она је потврђена у нашем истраживању, али је важно напоменути да се код 1. типа (паммтити - паิмтйм), 2. типа (личчити - ли́чйм) и 7а. типа (пећи - пече-м) сви акценти поклапају, па се такви случајеви не могу узимати у обзир за доказивање или оповргавање такве тврдње. Још је важније истаћи да се код 6б. типа (сла"ти - шӓљем, шӓљу - шаљљи), 7б. типа (држати - држим, држе- - држжи) и 10. типа (изнети - изнесе-м, изнесу- - изнесси) акценат императива разликује од акцената инфинитива.

Барић et al. (1997: 243) наводи и да већина глагола са наставцима наставцима -j, -jмо, -jmе и с наставцима -Ø, -мо, -те чува акценат презента. Ова тврдња важи за наш 5. и 8б. тип, али је само делимично тачна за 3б. и 4 б. тип, код којих акценат 3. лица множине презента има акценат инфинитива. Сви облици глагола 6а. типа имају исти акценат, па се не могу користити за доказивање ове тврдње.

\section{Закључак}

На основу анализе хиљаду најчешћих глагола, добијене су следеће акценатске парадигме: 1) памтити - памтйм, 2) ли́чити - ли́чим, 3) пи́сати - пишемм (са два подтипа: а) пи́сати - пишеме, пишу - пи́ши и б) спа́вати -

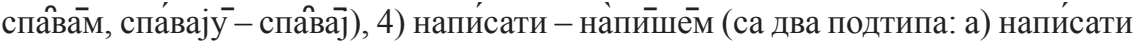

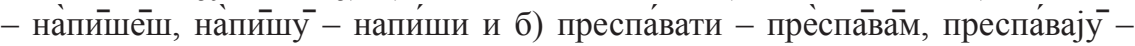
прѐспавај), 5) сарађи́вати - сарађујем, 6) вёровати - вёрујем, 7) пећи - пѐчемм, 8) изгубити - изгубйм, 9) слегнути - слёге-ем и 10) изне-ти - изнесе-м.

А на основу поређења акцента императива са осталим облицима, изводили смо следеће случајеве: сви испитани облици имају исти акценат (пример: личчити - ли́чим, личе- - ли́чи), императив има исти акценат као инфинитив, али различит од акцента презента (пример: пи́сати - пиิшем, пиюшу- - пи́ши), императив има исти акценат као оба испитана облика презента, али различит од акцента инфинитива (пример: сарађивати - сарађђујем - сара̀ђују - capàђj]), императив има исти акценат као 1. лице једнине презента, а различит акценат од 3. лица множине презента и инфинитива (пример: спа́вати 
- спа̂ва̄м, спа́вају - спа̂ва]) и императив има свој акценат, различит од свих испитаних облика (пример: слӓти - шӓљемм, шӓљу- - ша̀љи).

\section{Kopnyc:}

КССЈ: „Корпус савременог српског језика”, Математички факултет Универзитета у Београду, http://korpus.matf.bg.ac.rs/.

OP: Мирослав Николић, Обратни речник српскога језика. Београд: Матица српска, Институт за српски језик САНУ, Палчић, 2000.

PCJ: Речник српскога језика, измењено и поправљено издање. Нови Сад: Матица српска, 2011.

\section{ЛИТЕРАТУРА}

Барић et al. 1997: Euganija Barić, Mijo Lončarić, Dragica Malić, Slavko Pavešić, Mirko Peti, Vesna Zečević, Marina Znika, Hrvatska gramatika, II. promijenjeno izdanje, Zagreb: Školska knjiga.

Батас 2015: Ана Батас, „Акценат императива глагола I”, 45. међународни научни састанак слависта у Вукове дане, реферат са међународног скупа, Београд: Филолошки факултет, 15-18. IX 2015.

Даничић 1925: Ђуро Даничић, Српски акценти, Посебна издања, књига LVIII, Философски и филолошки списи, књига 16, Београд - Земун: Графички завод „Макарије”.

Јокановић Михајлов 2012: Јелица Јокановић-Михајлов, Прозодија и говорна култура, Београд: Друштво за спрски језик и књижевност Србије.

Николић 2007: Мирослав Николић, „Проблеми морфолошке анализе императива", Книжевност и језик, LIV/3-4, 241-248.

Стакић 2003: Милан Стакић, „Презент и императив у српском језику”, Кьижевност и језик, L/1-3, 171-177.

Стевановић 1991: Михаило Стевановић, Књига о акиенту књижевног јези$\kappa a$, Београд: Завод за уџбенике и наставна средства.

Стевановић 51989: Михаило Стевановић, Савремени српскохрватски језик. I. Увод. Фонетика. Морфологија, Београд: Научна књига [1964]. 
Ana S. Batas

\title{
THE ACCENT OF IMPERATIVE FORMS
}

\begin{abstract}
Summary
In this paper, the author analyses, from synchronic point of view, the accent paradigms of the verb forms in the Serbian language, based on 1000 the most frequent verbs. The main focus of this paper is the accent of imperative ( $2^{\text {nd }}$ person singular $)$ and its relations with the accents of infinitive and present tense $\left(1^{\text {st }}\right.$ person singular and $3^{\text {rd }}$ person plural $)$.
\end{abstract}

